\title{
1.はじめに - なせ光を使うのか
}

近年、光を使う診断の研究が盛んになってきている。中でも、光 C T が注目されている。光を使おうとす るのは、光の持つ空間的ならひに分光学的分解能力を活用しようとするからである。すなわち、光の持つコ ヒーレント（あるいはインコヒーレント）性を用いれは、生体組織の高分解断層像が得られるであろうし、 また、可視・近赤外域での分光的手段によって生体組織内の生理活性化学種や病変化学種の投影デー夕の取 得が可能となれば、それら化学種の分布についての C T 像が得られ、生理活性機能の空間分解診断、病変形、 病変種やその部位の同定などが可能となると考えられるからである。光 C Tを中心にして、それ以外の方法 による光イメージングの可能性も含めて、光診断の問題点を以下に考えよう。

\section{2. 光 C T の原理}

生体組織は0.7 - $1 \mu \mathrm{m}$ の近赤外光に対して比較的大きな透過革を持っている。したがって、この波長域の 光を用いて、生体組織内部に分布する化学種の光吸収にもとづ C T 構成できそうである。しかし、生体 組織は、光に対して高度な散乱体であるため、散乱成分を伴わないX線 C Tについて現在確立している $\mathrm{T} T$ アルコリズムをそのまま光 C T に適用することができない。

X線 C T に用いられているC T アルゴリスムは、多数の直線上の吸収係数の櫴分值- いわゆる投影デー夕 一をフーリエ変換することにより、吸収係数の分布、すなわち、C T 像を再構成しようとするものであり、 このアルコリスムが適用できるためには、生体試料内通過距離Zに対する光検出強度の変化割合がLambertBeer則を満足するものでなければならない。X線に対しては、このことが保証されている。

光に対してはどうであろうか。散乱・吸収媒質中の光の伝搬は散乱理論によって扱われる [1]。強度 1 。の光 が吸収係数ならひにに散乱係数の分布 $\mu_{a}(z), \mu_{a}(z)$ を持つ厚さdの吸収·散乱試料を通過した（z方向）とき、こ れをある受光角で検出すると、その検出強度 Iaは、散乱理論より次式で表される。

$$
\left.I_{\mathbf{a}}=I_{0}\left(\exp \left(\int_{0}^{a}-\left(\mu_{\mathbf{a}}(z)+\mu_{\mathbf{a}}(z)\right) d z\right)+q \exp \left(\int_{0}^{a}-\mu_{\mathbf{a}}(z) d z\right)-\exp \left(\int_{0}^{a}-\left(\mu_{\mathbf{a}}(z)+\mu_{\mathbf{s}}(z)\right) d z\right)\right\}\right)
$$

ただし、 $q(<1)$ は全散乱光パワーの受光角内への寄与斚である。右辺第 1 項の対数変換が投影データとなる べきものであり、第 2 項が散乱光のうちの検出成分への寄与分である。必要なのは先にも述べたように投影 データであるから、検出強度 $\mathrm{I}$ a中から右辺第 1 項のみを選別抽出すればよい。第 1 項のみが抽出できたとす れば、娭出強度IaがLambert-Beer則を満足することは明かであり、C Tアルコリズムが適用できる。さらに、 生体組織による散乱係数の分布が比較的一様である場合には、吸収係数についての投影データが分離でき、 C Tアルコリスムによって吸収 C T 画像が再楎成できることになる。

\section{3. 光 $\mathrm{C} \mathrm{T}$ 実現の方法}

問題は、右辺第 1 項のみを如何にして選別抽出して投影デー夕を取得するかである。それに応じて、光 C T実現に種々の方法が考えられている。

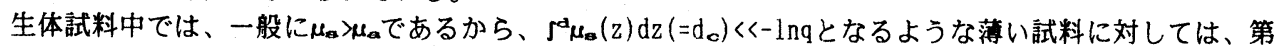
1 項〉第 2 項で投影データの取得可能であるが、 $\mathrm{d}_{e}$ 》〉-lnqとなるような厚い試料では、第 1 項《第 2 項とな つて、投影テータの取得が困難になる。そこで、q《1とすることで、厚い試料までの投影デー夕の取得を可 能としようとする方法が先ず考えられる。qくく1とするためには、試料透過光の出射方向を空間的に選別すれ ばよい。これを空間的選別法と呼ぶ。具体的には、一定方向の参照光を用い、干涉によって透過光の方向を 選別したり [2]、検出器の手前にダブルピンホールによるコリメータを置いて方向選別する [3]などの方法が 提案されている。散乱体の標準試料としてよく使われる”Intralipid-10\%”（脂質エマルジョン）水溶液につ いて、(1)式の成立をチェックした実験結果をFIG.1に示す。受光角 $=2.5 \times 10^{-4} \mathrm{rad}$ 、散乱係数 $\mu_{\mathrm{a}}=3.2 \mathrm{~cm}^{-1}$ に対 して、Lambert-Beer則成立距離は8cm程度ということになる。また、FIG.2に、空間的選別法のみによって得 
平成 6 年レーザー学会学術講演会第14回年次大会

られた、簡易ファントム("Intralipid-10\%”水溶液中に円柱状吸収体を置いた)に対する C T 像再構成の 1 例 を示す。

空間的選別法に対して時間的な方法も種々提案されていれる。これは、生体試料中の光をFIG.3に示すよ うに光子の流れと見れば理解しやすい。生体試料中を通過する光子は多重散乱を受けるが、多重散乱光子の うちにも、光源一検出器を結ぶ直線のまわりに仮想した微小断面柱状体中を通過する光子が、ある割合で存 在し、これが第 1 項の投影データを形成する。一方、多重散乱によって柱状体外を迂回して検出光に寄与す る光子が第 2 項の散乱検出成分を形成する。そこで、投影テータ収集にパルス光を用いれは、柱状体通過光 子の通過距離が一般散乱光のそれよりも短いことから、通過検出パルスの前縁部にのみ第 1 項の投影でテー 夕成分が集中するので、これを時間的なゲートによって選別することができる。時間ゲートとしては、スト リークカメラの利用 [4]、非線形光学奻果によるサンプリング法、具体的には、S H G を用いるもの[5]、誘 導ラマン散乱を用いるもの[6] などがある。FIG.4に、ストリークカメラ時間ゲートによる投影デー夕取得 改善の例 [7] を示す。実用的な光 C $\mathrm{T}$ 実現のためには、測定時間の節約、空間的分解能なとの点から、空間 的方法と時間的方法の適当な組み合わせが必要となろう $[8]$ 。非線形光学効果を用いたサンプリング法は、 強力なサンプリング (参照) パルスを用いることによって、サンプリング利得を得る可能性があり、実用的 光 C T 実現に向けての最有力な手段の一つとなろう。

4. 光 C T 以外の光による生体のイメージンク

4.1 低コヒーレント光リフレクトメトリー--- OLCR

光 C T のごとき画像再楎成によって横断面内の断層像を得るのではなく、レーダー方式によってリフレク トメトリックに奥行き方向の断層像を得る方法について、最近いくつかの新しい高分解な方法が提案されて いる。従来、リフレクトメトリックな方法としては、ピコ秒パルスを生体表皮から入射し、そのエコーを画 像化することが行われているか、その分解能は、当然パルス幅によって決まってしまい、散乱による到達可 能距離の制限に比べて、十分なものではなかった。新しい方法は参照光を使うコヒーレントな方法で、低コ ヒーレント光リフレクトメトリー(OLCR；Optical Low Coherence Reflectometry)と呼ばれる[9]。OLCRは、 スーパールミネッセントダイオードのごとき、ある程度の空間コヒーレンスを持ちながら、コヒーレンス時 間の短い光源を用いる時間領域リフレクトメトリーの総称である。干涉計配置によって、光源からの光を 2 分し、一方を参照光として掃引し、対象物からのエコー光との干渉信号を検出する。検出シグナルの掃引に よる相互荤延についての半値半幅 $\Delta$ 法、光源の低コヒーレンス性のため非常に短く、 $\Delta z=\mathrm{v}_{\mathrm{g}} / 2 \Delta \nu て ゙$ 近似でき

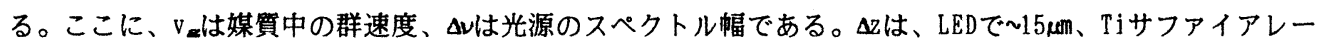

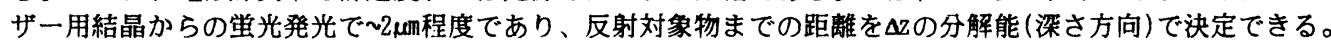
横断面内の分解能についても: 参照光との干跦検出であることから、光源の空間的コヒーレンスで決まり、 深さ方向と同程度までとれる。OLCRは表皮に近い生体組織の反射プロファイルを地オーダーの高分解能で得 るのに適している。検出を参照光との間でコヒーレントに行っているので、量子雓音限界までの検出が可能 で、高分解能を維持しながら、より厚いサンブルにまで適用可能と考えられる。FIG.5に、Michelson干渉計 構成としたOLCRの例[10]と、得られた人の網膜の断層像を示す。視神経頭部付近の断層楎造が深さ方向分解 能へ10 程度で鮮明に写し出されている。

\section{2 拡散光子密度波 -- DPDW}

散乱媒質が高密度になると、光子の多重散乱は拻散で記述できるようになる。従来、拡散光は、先の光 C Tでも述べたように、イメージンク情報を全く含まないものとして、これを如何に除去するかか問題であっ た。この拡散光を変調することによって、逆にイメージングに使おうというのが、拡散光子密度波 (DPDW; Diffuse Photon Density Have)である[11]。拡散媒䝷内における光子密度は、当然、拡散方程式に支配さ れるか、その振動項は進行波の解を持つ。従って、拡散媒質内に置かれた光源を正弦波強度変調することに よってDPDHを発生することができる。DPDHは光エネルギーについてのスカラー波であり、その波長入は、拡 散媒質の拡散係数をD、変調周波数を岒して、 $\lambda=2 \pi(\mathrm{D} / \omega)^{1 / 2}$ で与えられる。Dは搪散媒質の湿度に反比例す

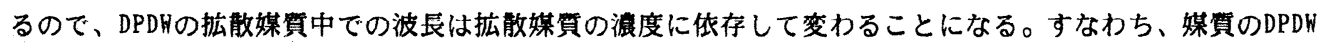
に対する屈折事が媒質の拡散媒質の湿度によってきまることとなる。Fig.6は濐度の異なる拡散媒質 (Intra$1 \mathrm{ipid}$ ) 水楁液の境界面 (ガラス板)におけるDPDW ( $\lambda=816 \mathrm{~nm}, \omega / 2 \pi=200 \mathrm{MHz}$ )の屈折の有榚を等位相面を検出する ことによって示したテモンストレーションである。Snel1の法則が成立していることがかかるこれ以外に も、DPDHについて幾何光学の法則が成り立つことが示されている。この結果は、光拡散媒質はDPDHに対して 
平成 6 年レーザー学会学術講演会第 14 回年次大会

あたかも透明媒質のように振舞うことを意味しており、生体のごとき強散乱体を透視するのにDPDHが有力な ッールになるものと思われる。

\section{5.おわりに}

光C Tとそれ以外の方法による光イメージングを中心にして、光診断の可能性を考えてきた。以上に見て きたように、この分野の研究は、新しいアイテ仍を出しあっている段階にある。夢はあるか、実際診断へ の応用には、まだまだ長い道のりを残していると言わさるを得ない。しかし、光診断によってもたらされる であろう情報は、はじめにも述べたように、生理活性や病理情報など、多量の診断情報を含んでいるので、 これが実現すれは、現在、無侵慗診断技術として確立し広く普及しつつあるX線 C T や、超音波、M R I 、 $\mathrm{P} E \mathrm{~T}$ などと共に補完的に使われることによって、無侵襲診断技術が飛躍的な進歩を遂げることが期待でき る。光診断がX線のような被曝を伴わないことも大きなメリットである。このことは高頻度の診断を可能と し、来るべき長寿社会の健康管理に欠かせないものとなるだろう。

\section{参考文献}

[1] A.Ishimaru, "Wave Propagation and Scattering in Random Media Vol.2", Chap.14, Academic Press, 1978.

[2] 戸井田昌宏,稲場文男, 応用物理, 62, 10 (1993)。

[3] Y.Cho, T.Shiota, K.Wada, T.Umeda, M.0sawa, 1993 CLE0 Technical Digest Series, vol.11, 128 (1993).

[4] F.Kawaguchi et al., Med. Biol. Eng. Comput., 29(Supp1.2), 959 (1991).

[5] 張吉夫,神田昌彦,特開昭63-206655, U.S.Pat 4,832,035, EPC 0280986 (1988).

[6] M.Bashkansky, C.L.Adler, R.Machon, J.Prewitt, J.Reintjes, 1993 CLE0 Technical Digest Series, vol.11, 98 (1993).

[7] B.B.Dass, K.M.Yoo, and R.R.Alfano, Optics Letters, 18, 1092 (1993).

[8] 吉野博紀,和田健司, 張吉夫, 信学技報, ED93-68, 0Q93-51，75 (1993).

[9] R.P. Salathe, 1993 CLEO Technical Digest Series, vol.11, 122 (1993).

[10] E.A.Swanson, J.A.Izatt, J.G.Fujimoto, Optics Letters, 18, 1864 (1993).

[11] M.A.0'Leary, D.A.Baos, S.Chance, A.G.Yodh, 1993 CLEO Technical Digest Series, vol.11, 124 (1993).

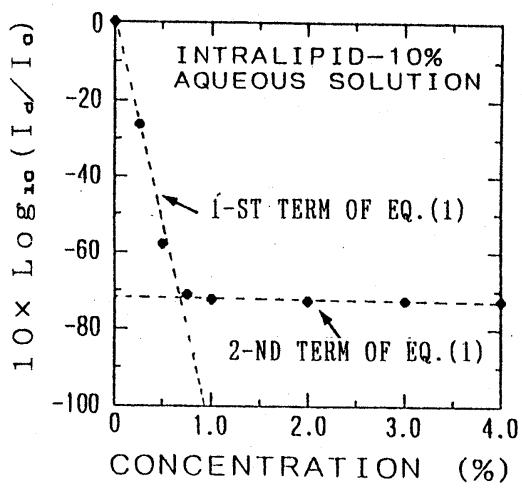

FIG.1 Experimental check of Eq.(1). Scattering medium: "Intra-lipid-10\%" aqueous solution, $\mu_{\mathrm{a}}=0, \mu_{\mathrm{a}} /(1 \%$ concentration $)=$ const $=3.2 \mathrm{~cm}^{-1}$, and cell leng th $=8 \mathrm{~cm}$.
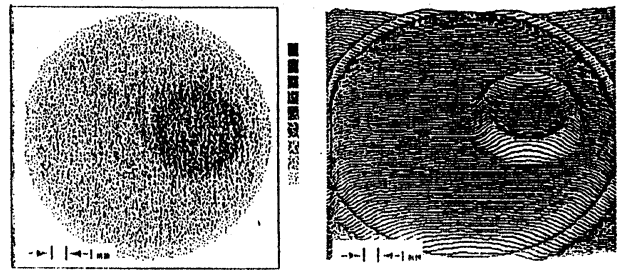

FIG.2 An example of CT reconstrucled image obtained by the spatial discrimination scheme [3]. Phantom is an absorbing cylinder $(5-\mathrm{mm}$ dia.) immersed in "Intralipid-10\%" $1 \%$ acqueous solution. Cell length is $8 \mathrm{~cm}$. 


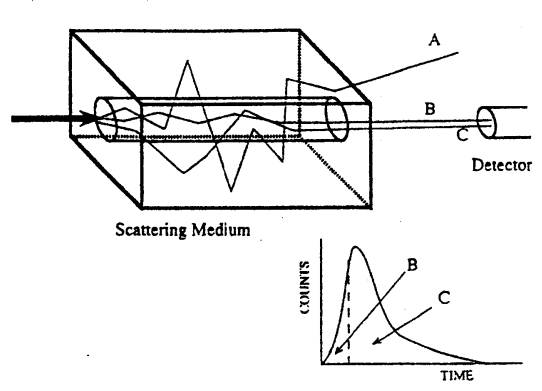

FIG.3 Photon trajectories in a scattering medium and transmitted pulse shape. Trajectory A for scattered out photon that is not detected, $B$ for photon traveling along a virtual thin cylinder that is detected, $C$ for scattered photon that is deteced. Leading edge of pulse comprises photons $A$ and trailing part comprises photons $B$.
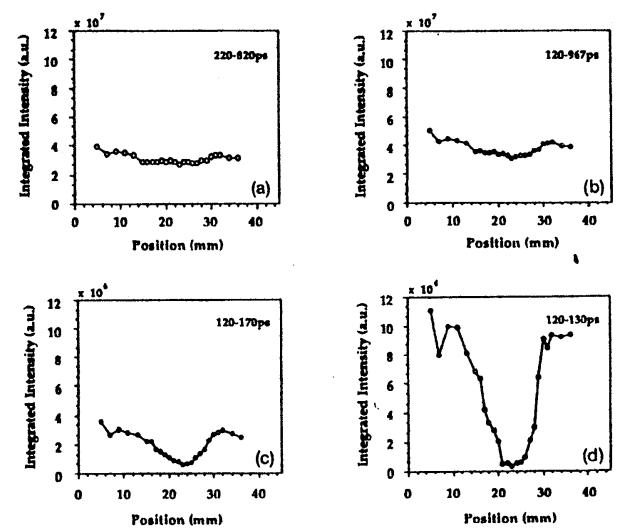

FIG.4 Improvement of projection data acquisition by time gates [7]. Phantom is a chicken fat peice placed in chicken breast tissue of $2.6-\mathrm{cm}$ thick. Dip shows the presence of fat piece. Time gate: (a) $220-820 \mathrm{ps}$, (b) $120-967 \mathrm{ps}$, (c) $120-170 \mathrm{ps}$, (d) $120-$ $130 \mathrm{ps}$.
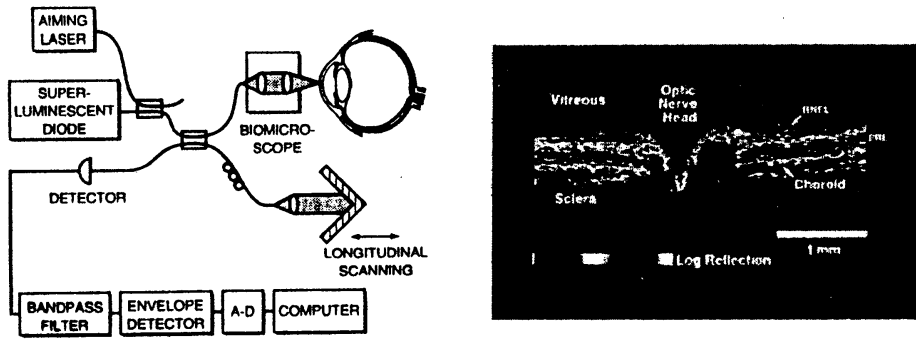

FIG.5 Schematic of OLCR system and an example of obtained tompgraphic image of the optic nerve head [10]. The System consists of a fiber-optic Michelson interferometer.

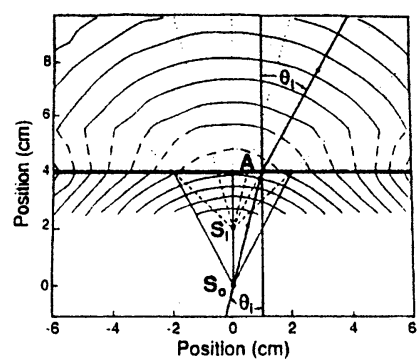

FIG.6 Constant phase contours of DPDH observed at a glass-plate boundary that separates $1 \%$ concentrated Intralipid from $0.25 \%$ Intralipid. So source, $S_{1}$ apparent source [11]. 